\title{
DEVELOPMENT OF QUANTITATIVE DETECTION METHOD FOR Meloidogyne incognita BY qPCR
}

\author{
DESENVOLVIMENTO DO MÉTODO DE DETECÇÃO QUANTITATIVO PARA \\ Meloidogyne incognita $P O R$ qPCR
}

\section{Camilla Martins de OLIVEIRA ${ }^{1}$; Ismail Teodoro de SOUZA JÚNIOR ${ }^{2}$; Nayane Oliveira ALMEIDA ${ }^{3}$; Marcos Augusto de FREITAS ${ }^{4}$; Mara Rúbia da ROCHA ${ }^{5}$; Silvana PETROFEZA ${ }^{6}$}

1. Doutoranda em Ciências Biológicas da Universidade Federal de Goiás - UFG, Goiânia, GO, Brasil. camillam.08@gmail.com; 2. Pós - doutorando em Fitossanidade da Universidade Federal de Pelotas - UFPEL; 3. Doutoranda em Agronomia - Fitossanidade da Universidade Federal de Goiás-UFG, Goiânia, GO, Brasil.; 4. Doutor, Fitopatologista da JEM Análise Agrícola, Aparecida de Goiânia, Brazil.; 5. Professora Titular, Doutora, Escola de Agronomia, Universidade Federal de Goiás - UFG, Goiânia, GO, Brasil.; 5. Professora Titular, Doutora, Instituto de Ciências Biológicas, Universidade Federal de Goiás - UFG, Goiânia, GO, Brasil.

\begin{abstract}
The root-knot nematode (Meloidogyne spp.) is the most important plant-parasitic nematode genus, they are the most common and destructive pathogens in this group. They produce some of the most drastic symptoms in plants and can significantly reduce the yield of crops. In order to achieve deploy an efficient method of plant-parasitic nematode management, is necessary an identification and quantification accurate and reliable of plant-parasitic nematodes. The aim of this study was to analyze samples in qPCR to detect and quantify $M$. incognita, in the field samples, comparing different methods of extraction of DNA and its efficacy in establishing the number of individuals. For this purpose the effectiveness of different DNA methods of extraction was compared through the values of CT intervals. For standard curve and method comparisons, we used nematodes multiplied in a greenhouse and carefully separated in the specific quantities of the experiments. For the number of individuals experiment field samples previously counted under an optical microscope were used. The DNA extraction was made from 100 nematodes by the methods: CTAB, Phenol: Chloroform and commercial kit (PureLink ${ }^{\circledR}$ Genomic DNA Kit, Invitrogen). In the comparative analysis using the three methods of DNA extracting from 100 nematodes, it was observed that commercial kit and CTAB methods obtained CT values similar. The CTAB method of extraction, showed less variation in the repeats and greater linearity of standard curve in comparison with other methods tested. So, it was possible to quantify the samples through the CT value intervals, established from different numbers of individuals $(1,10,25,100,250$, 500 and 750), in field samples. This study demonstrated that qPCR technique is an alternative sensitive and reliable for the quantification of $M$. incognita to support laboratories of diagnose and field survey.
\end{abstract}

KEYWORDS: Diagnostics. Monitoring. Root-knot nematode. Technique.

\section{INTRODUCTION}

Embrapa (2011) has estimated that nearly $5 \%$ of the soybean annual production is lost due to the nematode's action. The Brazilian Society of Nematology data have shown that the loss caused by the plant-parasitic nematodes in the country ranges from $5 \%$ to $35 \%$ considering the different kinds of culture. The Root-Knot nematodes (Meloidogyne Goeldi) are the most common and most destructive among this group of plant-parasitic nematodes. They can meaningfully reduce the culture's production and are found in almost all the farming places around the world, attacking a wide range of hosts (BAILEY et al., 2008). This makes them extremely difficult to control.

In order to be able to set an efficient method of handling these plant-parasitic nematodes, it is necessary a reliable identification of their species and quantification. These information are important to get an efficient control of the sustainable agriculture (CLAPP et al., 2000). The identification and quantification of the nematodes by most of the laboratories are done by the optical microscope. However, with the development of new tools of identification and measurement, there is an agreement in the scientific community that they must use these new techniques in order to get more accurate distinction of the species and quantification of the nematodes (SILVA et al., 2014).

The qPCR is a technique based on the DNA's analysis that allows the identification and quantification of the amplicon target by monitoring the fluorescence accumulation based on the threshold cycle's value (CT) (HEID et al., 1996). The advantages of this technique are: facility in 
measurement, more sensitive, more accuracy, reproducibility, speed in analysis and better quality control and less risk of contamination (NOVAIS et al., 2004).

The qPCR applicability to detect the plantparasitic nematodes has been tested in different researches, suggesting a practical approach for the Meloidogyne spp. quantification in field sampling (MADANI et al., 2008; BERRY et al., 2008; TOYOTA et al., 2008; ZHAO et al., 2010; MIN et al., 2011). Recent researches have discussed other kinds of nematodes of agronomic importance using this technique. Mokrini et al. (2013) have developed an accurate and fast method to detect and measure the Pratylenchus penetrans using the qPCR. Another research tested the qPCR's sample in order to detect and quantify the $P$. neglectus, directly from nematode's DNA extracted from the soil, to establish the applicability of field samples infested by this nematode in different population densities (YAN et al., 2011). These papers have shown a high linkage between the standard curve and the real number of nematodes.

Different methods of DNA's extraction have been tested to detect and quantify the nematodes by using different buffers of cell lysis like: $\mathrm{NaOH}$ (BERRY et al., 2008), Tween (YAN et al., 2011), $\mathrm{NaCl}$ (AL-BANNA et al., 2004; HOLTERMAN et al., 2006; MOKRINI et al., 2013), Phenol-Chloroform (DONG et al., 2001; FRANÇOIS et al., 2007), Chloroform-alcohol (BULMAN; MARSHALL, 1997) and Triton X-100 (ZHAO et al.,2010). It also has been used in different physical methods of DNA extraction to the cell lysis like Zirconia Beads and glass pearls (SATO et al., 2007; TOYOTA et al., 2008; MIN et al.,2011), as well as methods to develop the final quality of the DNA like commercial kits of DNA extraction and K protein (OLIVEIRA et al., 2009). The nematode development phase is also important since a few studies have shown extraction of DNA in a different life stage like second-stage juvenile (J2) and females (YAN et al., 2011; MIN et al., 2011), eggs (CARNEIRO et al., 2004; TOYOTA et al., 2008), directly from galls (DONG et al., 2001; HU et al., 2011) and samples with a mix of some developmental stage (BERRY et al., 2008; YAN et al., 2011; MOKRINI et al., 2013).

Assay of qPCR used for identification and quantification has also made it possible to deal with a big number of samples by automation that increase the velocity and accuracy of the extraction procedures. The quantitative PCR was also used in assays in the greenhouse (GAO et al., 2006) and in field to determine the effects of different treatments.
Other samples with qPCR have provided ecologic tools to study and quantify specific species within populations (HOLTERMAN et al., 2006; SATO et al., 2007) and interaction studies where the nematodes are inside the host (GAO et al., 2006; FRANÇOIS et al., 2007).

This study aimed to analyze samples using qPCR to detect and quantify $M$. incognita in study of the field samples, comparing different methods of extraction of DNA and its efficacy in establishing the number of individuals. This study suggests a practical approach to quantify $M$. incognita in field samples.

\section{MATERIAL AND METHODS}

The M. incognita isolate used in this study was obtained from inoculum source multiplied in tomato (Solanum lycopersicum) 'Santa Cruz', maintained in a greenhouse under controlled conditions of temperature $\left(21^{\circ} \mathrm{C}\right.$ to $\left.30^{\circ} \mathrm{C}\right)$, in the Agronomy School of Universidade Federal de Goiás. The isolates were identified through a perineal cutting and an esterase profile according to the methodology described by Carneiro and Almeida (2001). The nematodes were extracted from the tomato roots by the method of Coolen and D'Herde (1972). For standard curve and method comparisons, we used nematodes multiplied in a greenhouse and carefully separated in the specific quantities of the experiments, with the aid of a magnifying glass. For standardization of the qPCR was used the absolute quantification method with diluted patterns of DNA for the construction of the calibration curve (90 ng to $0.000009 \mathrm{ng}$ ) and extraction of DNA by the CTAB method.

To determine the number of individuals, preliminary tests were made and selected quantities. The test involved samples with 1, 10, 25, 100, 250, 500 and 750 nematodes from field samples collected and sent to the laboratory. The samples were previously counted under optical microscope, and contained nematodes of different developmental stages, as well as free-living nematodes and other important genera.

For the genomic DNA extraction, the methods were used: CTAB (Cetyltrimethylammonium bromide), described by Zolan and Pukilla (1986), the Phenol method: Chloroform described by Randig et al. (2002) and the commercial kit PureLink ${ }^{\circledR}$ Genomic DNA Kits (Invitrogen Corp., Carlsbad, CA, USA). For the DNA extraction with CTAB, first, each suspension containing the nematodes were centrifuged at $10.000 \mathrm{RPM}$ for $5 \mathrm{~min}$, and then the supernatant 
Development of quantitative...

was removed. Then the contents of the tubes were frozen in liquid nitrogen and then macerated with a glass rod aid. Were added to the samples $800 \mu \mathrm{L}$ of CTAB buffer $(2 \%$ CTAB, $1.4 \mathrm{M} \mathrm{NaCl}, 20 \mathrm{mM}$ EDTA, $100 \mathrm{mM}$ Tris-HCL, $\mathrm{pH} 8.0$ and $0.2 \%$ Bmercaptoethanol) preheated to $65^{\circ} \mathrm{C}$. Thus, the material was incubated for over $1 \mathrm{~h}$ at this temperature, with shaking every $10 \mathrm{~min}$. Were added $600 \mu \mathrm{L}$ of chloroform-isoamylalcohol and the tube was shaken manually for $10 \mathrm{~min}$. It was centrifuged for $10 \mathrm{~min}$ at $10.000 \mathrm{rpm}$ and transferred the aqueous phase to a new tube, then added $600 \mu \mathrm{L}$ of isopropanol and mixed by tube inversion. Again, the material was centrifuged for $10 \mathrm{~min}$ at $10.000 \mathrm{rpm}$. The supernatant was discarded and was added about $1 \mathrm{~mL}$ of ethanol $70 \%$, and then centrifuged for $10 \mathrm{~min}$ at $10.000 \mathrm{rpm}$. The supernatant was discarded, leaving the drying supernatant. The precipitate was resuspended in 20 $\mu \mathrm{l}$ of sterile water (miliQ) and stored at $-20^{\circ} \mathrm{C}$ until the use.

For the extraction by the Phenol: Chloroform was used the method described by Randig et al. (2002). Briefly, nematodes were macerated in liquid nitrogen with the aid of a glass rod. To the macerate was added $500 \mu \mathrm{L}$ of NIB buffer $(0.1 \mathrm{M} \mathrm{NaCl} ; 30 \mathrm{mM}$ Tris $\mathrm{pH} 8 ; 10 \mathrm{mM}$ EDTA; $0.7 \mathrm{mM} \beta$-mercaptoethanol; $5 \mathrm{mM}$ Triton NPHO). After homogenization, the samples were centrifuged twice at $10.000 \mathrm{rpm}$ for $2 \mathrm{~min}$ and the supernatant was removed. Then, were added $800 \mu \mathrm{L}$ of homogenization buffer $(0.1 \mathrm{M} \mathrm{NaCl} ; 0.2 \mathrm{M}$ saccharose; $10 \mathrm{mM}$ EDTA) and $200 \mu \mathrm{L}$ of lysis buffer $(0,125 \mathrm{M}$ EDTA; 0,5 M Tris pH 9.2; $2.3 \%$ SDS). After homogenization, the samples were incubated at $55^{\circ} \mathrm{C}$ for $30 \mathrm{~min}$, followed by $10 \mathrm{~min}$ at ambient temperature. The purification was performed by adding $1 \mathrm{~mL}$ of buffered phenol $(\mathrm{pH}$ 8.0), followed by the homogenization and centrifugation at $10.000 \mathrm{rpm}$ for $3 \mathrm{~min}$. The supernatant was recovered and then mixed with 500 $\mu \mathrm{L}$ of phenol and $500 \mu \mathrm{L}$ of chloroform, then centrifuged at $10.000 \mathrm{rpm}$ for $3 \mathrm{~min}$. To the supernatant was added $200 \mu \mathrm{L}$ of ether and after centrifugation at $10.000 \mathrm{rpm}$ for $3 \mathrm{~min}$, this was removed with the aid of a micropipette. The precipitation was performed at $-20^{\circ} \mathrm{C}$ for $30 \mathrm{~min}$. Then a centrifugation was carried out at $10.000 \mathrm{rpm}$
OLIVEIRA, C. M. et al.

for $10 \mathrm{~min}$. The supernatant was discarded and $70 \%$ ethanol was added. After centrifugation at 10,000 $\mathrm{rpm}$ for $5 \mathrm{~min}$, the ethanol was removed. The precipitate was dried at ambient temperature, recovered in $20 \mu \mathrm{L}$ of sterile water (Milli-Q) and stored at $-20^{\circ} \mathrm{C}$. The commercial KIT PureLink ${ }^{\circledR}$ Genomic DNA Kits (Invitrogen Corp., Carlsbad, CA, USA) were tested and the DNA extraction of the nematodes was performed as described in the protocol provided by the manufacturer.

The oligonucleotides used in this experiment were developed by Toyota et al., (2008), RKNf- (5'GCT GGT GTC TAA GTG TTG CTG ATA C-3') and RKNr-(5'GAG CCT AGT GAT CCA CGA TAA G-3') which has an amplification product of $185 \mathrm{bp}$. The qPCR was performed in StepOnePlus TM Real-Time PCR System device (Life Technologies, Foster City, CA, USA) in a final volume of $10 \mu \mathrm{L}$ containing $5 \mathrm{~mL}$ of Master Mix SYBR GREEN (Applied Biosystems, Carlsbad, CA, USA) $0.2 \mu \mathrm{L}$ of DNA, $0.2 \mu \mathrm{M}$ of each oligonucleotide primer. The reaction conditions were: $95^{\circ} \mathrm{C}$ for $10 \mathrm{sec} ; 45$ cycles of $95^{\circ} \mathrm{C}$ for $5 \mathrm{sec}$, $60^{\circ} \mathrm{C}$ for $30 \mathrm{sec}$. Reactions were performed in triplicates and the results of the amplification curve and threshold cycle values (CT) were analyzed.

\section{RESULTS}

In the qPCR analysis it was observed that the reaction efficiency of amplification with the oligonucleotides proposed by Toyota et al. (2008), obtained from the calibration curve with DNA patterns, it was $110 \%$ and with a slope value of 3.108 (Figure 1). These values are found within the range of -3.1 to -3.6 with $90-110 \%$ efficiency, which is considered to be a tolerable limit for the oligonucleotide amplification efficiency (RAYMAEKERS et al., 2009), demonstrating that the standard curve has obtained an acceptable oscillation.

The correlation coefficient $\left(\mathrm{R}^{2}\right)$ of the standard curve was 0.98 , indicating a linear relation between the CT value and the amount of DNA (Figure 1). The accuracy of the qPCR data between the three replicates with standard deviations ranged between 0.003 to 0.263 . 


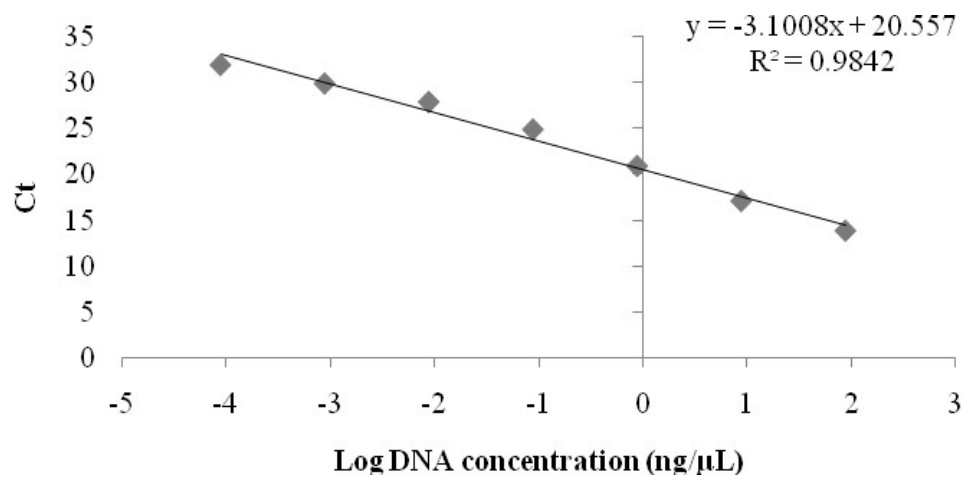

Figure 1. Calibration curve of DNA concentration (ng. $\mu \mathrm{L}-1)$ of Meloidogyne incognita in relation to the threshold cycle (CT).

In this study, two series of different dilutions were used to confirm the obtained result, which illustrates the sensitivity and linearity of the detection a wide range of DNA amount, where were obtained dilutions of 90 to 0.00009 ng. $\mu \mathrm{L}-1$ of the DNA patterns of $M$. incognita (Table 1). In the study of François et al. (2007), was obtained a $\mathrm{R}^{2}$ of
0.99 in a serial dilution of the DNA of Bursaphelenchus xylophilus (Steiner e Buhrer) Nickle, and obtained a dilution of 10 to 0.00001 ng. $\mu \mathrm{L}-1$ with quantification by TaqMan-PCR demonstrating high efficiency in the standard curve.

Table 1. Confidence interval of $99 \%$ between the mean values of the CT to the quantify of the extraction with CTAB.

\begin{tabular}{cccccc}
\hline Individuals number & Mean CT & Standard deviation & CI (99\%) & - & + \\
\hline 1 & 27 & 2.21 & 1.89 & 24.89 & 28.48 \\
100 & 19 & 0.59 & 1.05 & 17.86 & 19.86 \\
250 & 17 & 1.56 & 0.74 & 16.33 & 17.73 \\
750 & 15 & 1.08 & 0.61 & 14.87 & 16.03 \\
\hline
\end{tabular}

In the comparative analysis of the efficiency, estimated by $\mathrm{CT}$ obtained in qPCR, from the three DNA extraction methods (CTAB, Phenol: Chloroform and the PureLink ${ }^{\circledR}$ Genomic DNA Kits used from a sample of 100 nematodes (Figure 2) it was observed that the obtained results by $\mathrm{CTAB}$ method and commercial kit were with close CT values. Were observed low variations in CT values in samples extracted by the three methods, in the range of 100 individuals, these values were between 18 and 23 (Figure 2). The CT mean with the CTAB method was 18 and the extracted samples with Phenol: Chloroform was 19 for 100 nematodes and with a standard deviation of 0.58 for the repetitions.

The obtained CIs for the amount of 100 nematodes (Table 1), with the method of extraction by $\mathrm{CTAB}$ was between 17.86 to 19.86 corroborating the data obtained by François et al. (2007) for Bursaphelenchus xylophilus (BERRY Et al., 2008) for M. javanica, P. zeae and Xiphinema elongatum, (TOYOTA et al., 2008) for M. incognita (MOKRINI et al., 2013) and for P. penetrans, who obtained values of 15-20, 17-20, 20-21 and 24.4, respectively, however Mokrini et al., (2013) worked with an amount of 80 nematodes. In all the cases, the CT values are close even when submitted to different methods of DNA extraction and different species of nematodes, confirming the accuracy of this analysis.

Based on the obtained results, the extraction method with CTAB was chosen for DNA extraction of ranges $1,10,25,100,250,500$ and 750 nematodes. The qPCR data had demonstrated a 97\% amplification efficiency (Figure 3), being the $\mathrm{R}^{2}$ value $=0.93$. The standard deviations between the repetitions of the triplicates of each analysis range were between 0.58 and 3.2.

The mean CT data for the calculation of the confidence interval CI (Table 1) were validated with different random samples of the field, initially counted under an optical microscope and then made the DNA extraction of these samples and quantified by qPCR, being all the CTs obtained suitable to the established ranges by the initial count. The validation with field samples is important to demonstrate the reliability and accuracy of the used method. 


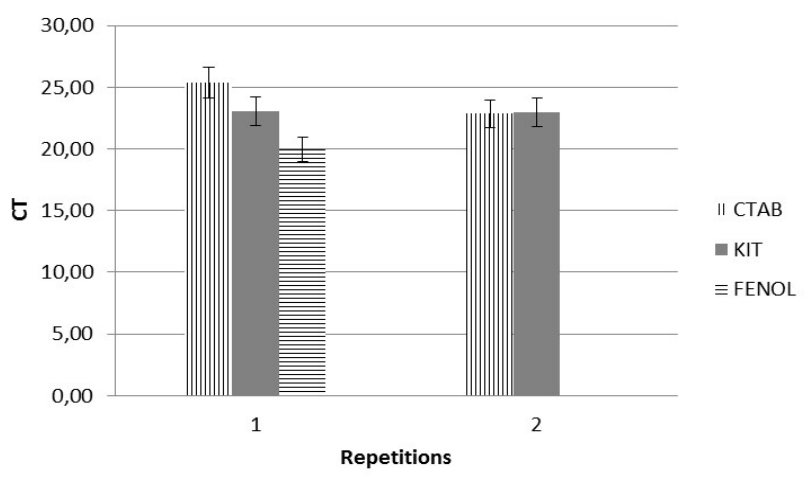

Figure 2. Comparison between the CT means of the field samples obtained with different methods of DNA extraction (CTAB, phenol: chloroform and PureLink ${ }^{\circledR}$ Genomic DNA Kit).

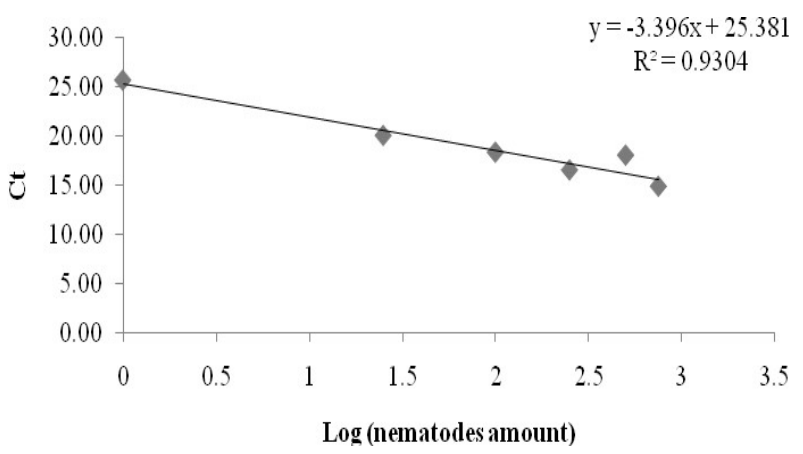

Figure 3. Amplification curve of the separated samples by amounts and extracted with CTAB.

\section{DISCUSSION}

As in the study of Mokrini et al. (2013), a serial dilution from $P$. penetrans DNA resulted in a standard curve which shows a highly significant linearity between $\mathrm{CT}$ values and dilution rate $\left(\mathrm{R}^{2}=\right.$ 0.99 ; slope $=-3.23 ; \mathrm{E}=104 \%$ ). The tests of Mokrini et al. (2013) showed a high correlation between the real numbers of nematodes and detected numbers by the qPCR. Studies have shown that a linear regression of $\mathrm{CT}$ values against the logarithm of the DNA concentration to potato cyst nematode (MADANI et al., 2007, 2008) and Meloidogyne spp. (TOYOTA et al., 2008). In these studies, serial dilutions of DNA were used as a model to generate a standard curve to evaluate the correlation between the mean $\mathrm{CT}$ and the estimate of the microscopic counts of the individual number in each sample.

In the comparative analysis of the efficiency, estimated by $\mathrm{CT}$ obtained in $\mathrm{qPCR}$, from the three DNA extraction methods (Figure 2) the results showed differents from the observed in the study of Zhao et al. (2010), in which comparison was made of different concentrations Triton X-100 method, which obtained with the comparison of the field analysis of samples containing 1 to 200 individuals a standard curve with low efficiency. These same authors have reported an underestimation of the nematodes number of $45 \%$, wherein the slope was $0.5521, \mathrm{R} 2=0.7154$. In contrast, using the CT value there was an overestimation which was shown by Toyota et al. (2008) where the slope was 1.515 and the R2 = 0.9391 .

In the present study was observed that in samples with large amounts of nematodes, above 750 individuals, the DNA was not extracted efficiently and consequently varies in relation to the sample, and thus do not present linearity with other data. This confirms the study of Zhao et al. (2010), where the sample with 1000 individuals did not show linearity as all other samples for the CT values. This suggests that the maximum number of nematodes must be lower than 1000 individuals in obtaining a good quality of the standard curve. According to the same authors, the same volume of lysis solution used for an individual was also applied in 1000 individuals, which can be carried more proteins and/or lipids in the sample containing 1000 individuals, which may have negatively affected the result of the PCR in real time. In the 
Development of quantitative...

study of Mokrini et al. (2013), the used DNA extraction method was stable and able to extract DNA from up to 80 individuals. However, five individuals were the maximum number of nematodes suggested to be used in the DNA extraction method, as described by Holterman et al. (2006).

In addition to the difficulties in the DNA extraction of the nematodes, we have in the Meloidogyne genus, that the number of cells has an increase during the different stages of their development. This data for this analysis does not have a great influence on the estimating of the number of nematodes in a field sample because the degree of precision required for agronomic and ecological studies will be much determined by factors such as a good sampling and an efficient extraction (MOKRINI et al., 2013). This result was confirmed in our research, since in the same sample had nematodes in different stages of development, since the goal was to have a greater approximation of the conditions found in the field, because in routine analysis of different life stages of these nematodes are not processed in conjunction, considering the most frequently used extraction methods.

The qPCR is gaining approval for the detection of pathogens. This method combines the amplification and detection steps in a single reaction in a closed tube, which minimizes the risk of sample contamination (WONG; MEDRANO, 2005). The advantages of using the qPCR in general are: possibility of quantitative detection of pathogens, potential for the use in a high number of samples
OLIVEIRA, C. M. et al.

and the absence of the need for post-PCR analysis, besides the rapidly of obtaining the data ( $\leq 1$ to $2 \mathrm{~h}$ ) (SCHAAD et al., 2002; DE BOER; WARD, 2007).

These results demonstrate the potential of this essay to provide a rapid, accurate and sensitive identification and molecular quantification of the root-knot nematode. The methodology for quantifying nematodes by qPCR presents an option that may in the future include other species of economic importance. The qPCR does not require experience in the taxonomy and morphology of nematodes, and can be used as a tool for quick diagnosis in the research and also in diagnostic laboratories and extension services to indicating the correct pest management.

\section{CONCLUSIONS}

The CTAB method (ZOLAN; PUKILLA, 1986) has proved to be the more indicated for $M$. incognita DNA extraction compared with the commercial KIT (PureLink ${ }^{\circledR}$ Genomic DNA Kits (Invitrogen Corp., Carlsbad, CA, USA) and the method of Phenol: Chloroform (RANDIG et al., 2002).

It is possible to quantify $M$. incognita from soil and roots samples by PCR in real time.

\section{ACKNOWLEDGMENT}

The authors thank to Fundação de Amparo à Pesquisa do Estado de Goiás (Fapeg) for the financial support given to this research.

RESUMO: Os nematoides-das-galhas (Meloidogyne spp.) é o gênero de fitonematoide mais importante, são os patógenos mais comuns e destrutivos deste grupo. Eles produzem alguns dos sintomas mais drásticos nas plantas e podem reduzir significativamente o rendimento das culturas. Para conseguir implantar um método eficiente de manejo de nematoides parasitas de plantas, é necessária a identificação e quantificação precisa e confiável dos fitonematoides. O objetivo deste estudo foi analisar amostras em qPCR para detectar e quantificar $M$. incognita, em amostras de campo, comparando diferentes métodos de extração do DNA e sua eficácia no estabelecimento do número de indivíduos. Para este propósito, a eficácia de diferentes métodos de extração de DNA foi comparada através dos valores dos intervalos de $\mathrm{Ct}$. Para comparações padrão de curvas e métodos, usamos nematoides multiplicados em casa de vegetação e cuidadosamente separados nas quantidades específicas dos experimentos. Para o número de indivíduos, foram utilizadas amostras de campo previamente contadas sob um microscópio óptico. A extração de DNA foi realizada a partir de 100 nematoides, pelos métodos: CTAB, Phenol: Clorofórmio e kit comercial (PureLink® Genomic DNA Kit, Invitrogen). Na análise comparativa utilizando os três métodos de extração de DNA a partir de 100 nematoides, observou-se que o kit comercial e os métodos de CTAB obtiveram valores de CT semelhantes. O método de extração CTAB apresentou menor variação nas repetições e maior linearidade da curva padrão em comparação com os demais métodos testados. O coeficiente de correlação (R2) da curva padrão foi de 0,98 indicando uma relação linear entre o valor de $\mathrm{Ct}$ e a quantidade de padrões de DNA variando de 90 a 0,00009 ng. $\mu \mathrm{L}-1$. Assim, foi possível quantificar as amostras através dos intervalos de valores de CT, estabelecidos a partir de diferentes números de indivíduos $(1,10,25,100,250,500$ e 750), em amostras de campo. Este estudo demonstrou que a técnica de 
Development of quantitative...

OLIVEIRA, C. M. et al.

qPCR é uma alternativa sensível e confiável para a quantificação de $M$. incognita, para apoiar laboratórios de diagnóstico e levantamentos de campo.

PALAVRAS-CHAVE: Diagnose. Monitoramento. Nematoide das galhas. Técnica.

\section{REFERENCES}

AL-BANNA, L.; PLOEG, A. T. V.; WILLIAMSON M.; KALOSHIAN, I. Discrimination of Six Pratylenchus Species Using PCR and Species-Specific Primers. Journal of Nematology, v. 36, n. 2, p. 142-146, 2004.

BAILEY, D. J.; BRIAN, G. L.; KERRY, B. R.; GILLIGAN, C. A. Pathozone dynamic of Meloidogyne incognita in the rhizosphere of tomato plants in the presence and absence of the nematophagous fungus, Pochonia chlamydosporia. Plant Pathology, v. 57, n. 5, p. 354-362, 2008. https://doi.org/10.1111/j.13653059.2007.01776.x

BERRY, S. D.; FARGETTE, M.; SPAULL, V. W.; MORAND, S.; CADET, P. Detection and quantification of root-knot nematode (Meloidogyne javanica), lesion nematode (Pratylenchus zeae) and dagger nematode (Xiphinema elongatum) parasites of sugarcane using real-time PCR. Molecular and Cellular Probes, v. 22, $\mathrm{n}$. 2, p. 168-176, 2008. https://doi.org/10.1016/j.mcp.2008.01.003

BULMAN, S. R.; MARSHALL, J. W. Differentiation of Australasian potato cyst nematode (PCN) populations using the polymerase chain reaction (PCR). New Zealand Journal of Crop and Horticultural Science, v. 25, n. 2, p. 123-129, 1997. https://doi.org/10.1080/01140671.1997.9513998

CARNEIRO, R. M. D.; ALMEIDA, M. R. A. Técnica de eletroforese usada no estudo de enzimas dos nematóides de galhas para identificação de espécie. Nematologia Brasileira, v. 25, n. 1, p. 35-44, 2001.

CARNEIRO, R. M. D. G.; TIGANO, M. S.; RANDIG, O.; ALMEIDA, M. R. A.; SARAH, J. L. Identification and genetic diversity of Meloidogyne spp. (Tylenchida: Meloidogynidae) on coffee from Brazil, Central America and Hawaii. Nematology, v. 6, n. 2, p. 287-298, 2004. https://doi.org/10.1163/1568541041217942

CLAPP, J. P.; VAN DER STOEL, C. D.; VAN DER PUTTEN, W. H. Rapid identification of cyst (Heterodera spp., Globodera spp.) and root-knot (Meloidogyne spp.) nematodes on the basis of ITS 2 sequence variation detected by PCR-single-strand conformational polymorphism (PCRSSCP) in cultures and fields samples. Molecular Ecology, v. 9, n. 1, p. 1223-1232, 2000. https://doi.org/10.1046/j.1365-294x.2000.00995.x

COOLEN, W. A.; D'HERDE, C. J. A method for the quantitative extraction of nematodes from plant tissue. Ghent: Nematology and Entomology Research Station, 1972.77p.

DE BOER, S. H.; WARD, L. PCR detection of Erwinia carotovora subsp. atroseptica associated with potato tissue. Phytopathology, v. 85, n. 5, p. 854-858, 2007. https://doi.org/10.1094/Phyto-85-854

DONG, K.; DEAN, R. A.; FORTNUM, B. A.; LEWIS, S. A. Development of PCR primers to identify species of root-knot nematodes: Meloidogyne arenaria, M. hapla, M. incognita, M. javanica. Nematropica, v. 31, n. 2, p. 271-280, 2001.

EMBRAPA, Empresa Brasileira de Pesquisa Agropecuária. Tecnologias de produção de soja, região central do Brasil 2012 e 2013. Londrina: Embrapa Soja. 2011. 262 p.

FRANÇOIS, C.; CASTAGNONE, C.; BOONHAM, N.; TOMLINSON, J.; LAWSON, R.; HOCKLAND, S.; QUILL, J.; VIEIRA, P.; MOTA, M.; CASTAGNONE-SERENO, P. Satellite DNA as a target for TaqMan realtime PCR detection of the pinewood nematode, Bursaphelenchus xylophilus. Molecular Plant Pathology, v. 8, n. 6, p. 803-80, 2007. https://doi.org/10.1111/j.1364-3703.2007.00434.x 
GAO, X.; JACKSON, T. A.; HARTMAN, G. L.; NIBLACK, T. L. Interactions between the soybean cyst nematode and Fusarium solani f. sp glycines based on greenhouse factorial experiments. Phytopathology, v. 96, n. 3, p. 1409-1415, 2006. https://doi.org/10.1094/PHYTO-96-1409

HEID, C. A.; STEVENS, J.; LIVAK, K. J.; WILLIAMS, P. M.. Real time quantitative PCR. Genome Research, v. 6, n. 10, p. 986-994, 1996. https://doi.org/10.1101/gr.6.10.986

HOLTERMAN, M.; WURFF, A. V. D.; ELSEN, S. V. D.; MEGEN, H. V.; BONGERS, T.; HOLOVACHOV, O.; BAKKER, J.; HELDER, J. Phylum wide analysis of SSU rDNA reveals deep phylogenetic relationships among nematodes and accelerated evolution to ward crown clades. Molecular Biology and Evolution, v. 23, n. 6, p. 1792-1800, 2006. https://doi.org/10.1093/molbev/ms1044

HU, M. X.; ZHUO, K.; LIAO, J. L. Multiplex PCR for the simultaneous identification and detection of Meloidogyne incognita, M. enterolobii and M. javanica using DNA extracted directly from individual galls. Nematology, v. 101, n. 11, p. 1270-1277, 2011. https://doi.org/10.1094/PHYTO-04-11-0095

MADANI, M.; SUBBOTIN S. A.; MOENS, M. Quantitative detection of the potato cyst nematode, Globodera pallida, and the beet cyst nematode, Heterodera schachtii, using real-time PCR with SYBR green I dye.

Mollecular and Cell Probes, v. 19, n. 7, p 81-86, 2007. https://doi.org/10.1016/j.mcp.2004.09.006

MADANI, M.; WARD, L. J.; BOER, S. H. Multiplex real-time polymerase chain reaction for identifying potato cyst nematodes, Globodera pallida and Globodera rostochiensis, and the tobacco cyst nematode, Globodera tabacum. Canadian Journal Plant Pathology, v. 30, n. 1, p. 554-564, 2008. https://doi.org/10.1080/07060660809507555

MIN, Y. Y.; TOYOTA, K.; GOTO, K.; SATO, E.; MIZUGUCHI, S.; ABE, N.; NAKANO, A.; SAWADO, E. Development of a direct quantitative detection method for Meloidogyne incognita in sandy soils and its application to sweet potato cultivated fields in Tokushima prefecture, Japan. Nematology, v. 13, n. 1, p. 95-102, 2011. https://doi.org/10.1163/138855410X504916

MOKRINI, F.; WAEYENBERGE, L.; VIAENE, N.; ANDALOUSSI, F. A.; ANDMOENS, M. Quantitative detection of the root-lesion nematode, Pratylenchus penetrans, using qPCR. European Journal of Plant Pathology, v. 137, n. 1, p. 403-413, 2013. https://doi.org/10.1007/s10658-013-0252-1

NOVAIS, C. M.; ALVES, M. P.; SILVA, F. F. PCR em tempo real. Revista Biotecnologia Ciência e Desenvolvimento, v. 33, n. 1, p. 10-13, 2004.

OLIVEIRA, C. M. G.; MACHADO, A. C. Z.; KUBO, R. K.; HARAKAVA, R. Diagnose de Aphelenchoides fragariae e Pratylenchus spp. pela aplicação da tecnologia do código de barras do DNA. Nematologia Brasileira, v. 33, n. 3, p. 218-225, 2009.

RANDIG, O.; BONGIOVANNI, M.; CARNEIRO, R. M; CASTAGNONE-SERENO, P. Genetic diversity of root-knot nematodes from Brazil and development of SCAR markers specific for the coffee-damaging species. Genome, v. 45, n. 3, p. 862-870, 2002. https://doi.org/10.1139/g02-054

RAYMAEKERS, M.; SMETS, R.; MAES, B.; CARTUYVELS, R. Checklist for optimization and validation of Real-Time PCR assays. Journal of Clinical Laboratory Analysis, v. 23, n. 3, p. 145-151, 2009.

https://doi.org/10.1002/jcla.20307

SATO, E.; MIN, Y.Y.; SHIRAKASHI, T.; WADA, S.; TOYOTA, K. Detection of the root-lesion nematode, Pratylenchus penetrans (Cobb), in a nematode community using real-time PCR. Japanese Journal of Nematology, v. 37, n. 2, p. 87-92, 2007. https://doi.org/10.3725/jjn.37.87

SCHAAD, N. W.; JONES, J. B.; CHUN, W. Laboratory Guide for identification of Plant Pathogenic Bacteria, 3 ed. St. Paul. The American Phytopathology Society, St. Paul, 2002. 373 p. 
TOYOTA, K.; SHIRAKASHI, T.; SATO, E.; WADA, S.; MIN, Y. Y. Development of a real-time PCR method for the potato-cyst nematode Globodera rostochiensis and the root-knot nematode Meloidogyne incognita. Soil Science and Plant Nutrition, v. 54, n. 5, p. 72-76, 2008. https://doi.org/10.1111/j.1747-0765.2007.00212.x

WONG, M. L.; MEDRANO, J. F. Real-time PCR for mRNA quantitation. Biotechniques, v. 39, n. 1, p. 75-85, 2005. https://doi.org/10.2144/05391RV01

YAN, W.; LUO, J.; ROBINSON, M.; AEBERSOLD, R. Index-ion triggered MS2 ion quantification: a novel proteomics approach for reproducible detection and quantification of targeted proteins in complex mixtures.

Molecular e Cellular Proteomic, v. 10, n. 1, p. 1-15, 2011. https://doi.org/10.1074/mcp.M1 10.005611

ZHAO, Y.; RUAN, W.; YU, L.; ZHANG, J.; FU, J.; SHAIN, E. B.; HUANG, X.; WANG, J. Combining maxRatio analysis with real-time PCR and its potential application for the prediction of Meloidogyne incognita in field samples. Journal of Nematology, v. 42, n. 1, p. 166-172, 2010.

ZOLAN, M. E.; PUKILLA, P. J. Inheritance of DNA methylation in Coprinus cinerus. Molecular and

Cellular Biology, v. 6, n. 1, p. 195-200, 1986. https://doi.org/10.1128/MCB.6.1.195 